\title{
Effect of cutting fluid and spindle speed on surface hardness in turning AISI 4140 steel
}

\author{
Iswanto ${ }^{1}$, Prantasi H. Tjahjanti' ${ }^{2}$, Edi Widodo ${ }^{3}$, Muchammad Chilmi ${ }^{4}$ \\ 1,2,3,4 Department of Mechanical Engineering, Universitas Muhammadiyah Sidoarjo \\ JI. Mojopahit 666 B Sidoarjo, 61215 \\ *Corresponding author: iswanto@umsida.ac.id
}

\begin{abstract}
This paper will discuss how the influence of different cutting fluid on surface hardness, how different spindle speed affect surface hardness, and are there interactions between cutting fluid and spindle speed on surface hardness of workpieces produced by conventional lathe. In this study, the variables that are varied are the cutting fluid and spindle speed. The cutting fluid used is: dromus, used oil SAE 40 and used cooking oil. While the spindle speed used is $370 \mathrm{rpm}, 665 \mathrm{rpm}$, and $1040 \mathrm{rpm}$. Then the hardness of the workpiece surface is tested from the lathe process by varying the cutting fluid and the spindle speed. From the results of the hardness test on the surface of the workpiece, it can be concluded that: the greatest value of the surface hardness of the workpiece is obtained in the lathe process using dromus cutting fluid and the spindle speed used is $665 \mathrm{rpm}$. Whereas the smallest workpiece surface hardness value is obtained when using dromus cutting fluid using spindle speed of $1040 \mathrm{rpm}$. Cutting Fluid and Spindle Speed has a significant effect on surface hardness in the turning process of AISI 4140 steel.
\end{abstract}

Keywords: Surface hardness, AISI 4140 steel, Spindle speed, Cutting fluids, Turning process.

\section{Introduction}

Lathe is a machine that can change the size or shape of a workpiece by cutting the workpiece with a tool $[1,2]$. The workpiece is held by a grip mounted at the end of the spindle, then the workpiece rotates following the spindle rotation. The tool moves translation left/right in the direction of the axis of the lathe to carry out the process of eating or slicing [3, 4]. During the turning process there is an interaction between the tool and the workpiece, then the workpiece will be cut off and become the desired shape [5, 6].

In the turning process, the workpiece experiences heat gain due to the cutting of the tool to the workpiece, which causes the impurity of the material and thus influences its properties [7, 8]. Mechanical properties namely strength and also corrosion strength, including their chemical properties, are affected by a small amount of impurities or micro defects. These properties are called structural changes, the hardness of the workpiece will change, also affect the chemical structure of the workpiece $[9,10]$. Surface properties such as hardness are very important for the functionality of engine components [11].

To get good turning results, there are several factors that must be considered, including: depth of cut, spindle speed and cutting fluid $[3,12]$. The cutting fluid has a special function in the machining process. Besides being able to extend tool life, cutting fluid in certain cases can reduce the force and smooth the surface of the machined product $[13,14]$.

Research on the effect of spindle speed or the influence of cutting fluid on the lathe process has been carried out, among others: Kumar, N. S. et. all researching about effect of spindle speed and feed rate on surface roughness of carbon steels in CNC turning [15]. Research conducted by Onuoha, U. J. et. all. about determining the effect of cutting 
fluids on surface roughness in turning AISI 1330 alloy steel using Taguchi method [16]. In a previous study of the effect of spindle speed and cutting fluid on the surface roughness of AISI 4140 steel in the turning process, the results showed that the spindle speed and cutting fluid affect the surface roughness of AISI 4140 steel [17]. From these results, this research will discuss about how the influence of the cutting fluid and spindle speed on the surface hardness of AISI 4140 steel in the turning process.

\section{Methods}

The first step taken in this research is to prepare research tools and materials. Tools and materials used, among others:

- Conventional lathe.

- Insert shape tool, WNMG 080408-DR, WNMG 6432-DR.

- Specimen material is AISI 4140 steel with a length of $15 \mathrm{~cm}$, diameter of 25 mm.

- There are three types of cutting fluid used, namely: dromus, used SAE 40 oil and used cooking oil.

- Rockwell type hardness test equipment.

Furthermore, the turning process is made to make the specimens to be tested for hardness. Turning process is done by varying the coolant and spindle speed, namely: 370, 665 and $1040 \mathrm{rpm}$. So that there are nine different treatment processes of turning on the specimen. The turning process is carried out three times with a cutting depth of $1 \mathrm{~mm}$ and a cutting speed of $60 \mathrm{~m} / \mathrm{min}$. So the dimensions of the workpiece/specimen that is formed as in Figure 1.

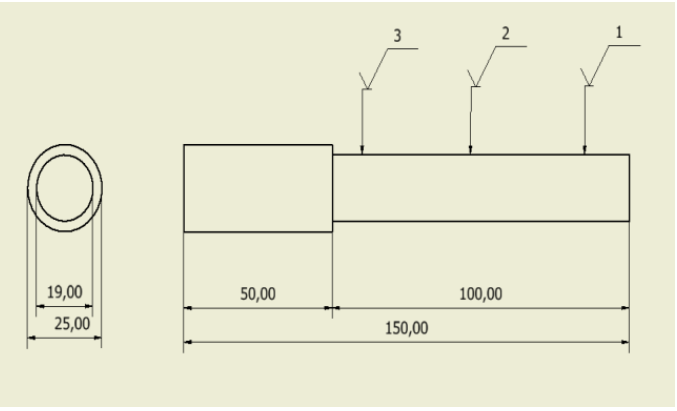

Figure 1. Dimensions of specimens
For cutting fluid, do not use these ingredients purely, but the material is diluted with added water. The ratio between the coolant with water is $1: 10$, while for the coolant to mix with water emulsifying agents are added in the form of liquid soap.

After the turning process is complete and the hardness test specimen is formed as desired, as shown in figure 2, the next step is to conduct the hardness test. Hardness testing is carried out at three different points / parts on each specimen, namely at the base, middle and end of the specimen. As shown in Figure 2, in the circled section.

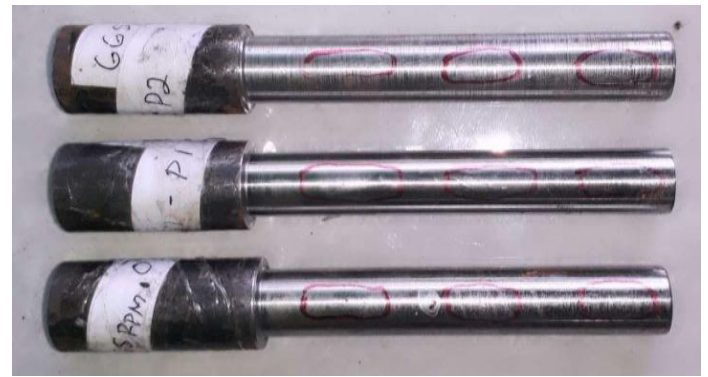

Figure 2. Hardness test specimens

After testing is complete and the hardness value data obtained from each specimen, then the data is analyzed using the two-way variant analysis method.

\section{Results and Discussion}

The data obtained in this study is the value of the surface hardness of the workpiece, which is influenced by differences in cutting fluid and spindle speed during the turning process. As shown in Table 1.

Table 1. Results of surface hardness measurements

\begin{tabular}{|c|c|c|c|}
\hline $\begin{array}{l}\text { Cutting } \\
\text { Fluid }\end{array}$ & $\begin{array}{l}\text { Depth of } \\
\text { Cut (mm) }\end{array}$ & $\begin{array}{c}\text { Spindle } \\
\text { Speed (rpm) }\end{array}$ & $\begin{array}{c}\text { Hardness } \\
\text { (HRC) }\end{array}$ \\
\hline \multirow{3}{*}{ Dromus } & \multirow{3}{*}{1} & 370 & 42.00 \\
\hline & & 665 & 53.50 \\
\hline & & 1040 & 37.25 \\
\hline \multirow{3}{*}{$\begin{array}{l}\text { Used oil } \\
\text { SAE } 40\end{array}$} & \multirow{3}{*}{1} & 370 & 44.33 \\
\hline & & 665 & 42.75 \\
\hline & & 1040 & 48.83 \\
\hline \multirow{3}{*}{$\begin{array}{l}\text { Used } \\
\text { cooking oil }\end{array}$} & \multirow{3}{*}{1} & 370 & 41.08 \\
\hline & & 665 & 41.66 \\
\hline & & 1040 & 45.75 \\
\hline
\end{tabular}




\section{Effect of cutting liquid on surface hardness}

Furthermore, data from table 1 made a graph of the relationship between different coolants to surface hardness as in Figure 3. From Figure 3 it can be seen that the coolant in the turning process produces a different surface hardness of the workpiece. The highest surface hardness occurs in dromus coolant, while the lowest surface hardness also occurs in dromus coolant but at different spindle speeds.

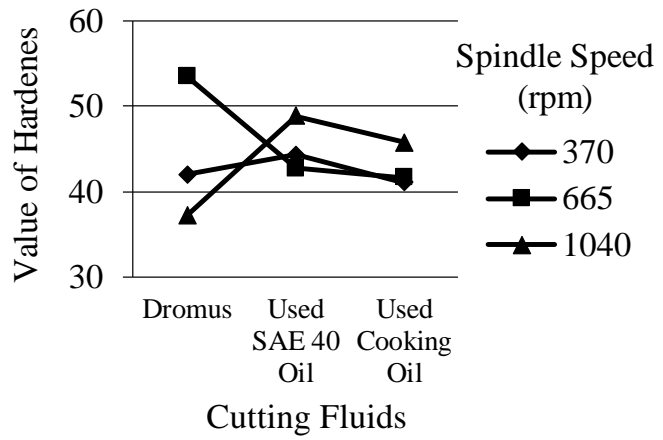

Figure 3. Graph of the relationship of cutting fluid to surface hardness

In turning process using dromus cutting fluid, resulting in fluctuating work surface hardness. The hardness of the workpiece surface tends to be high when the spindle speed is moderate and the workpiece surface hardness becomes low if the spindle speed used tends to be high. Whereas in the turning process that uses the used SAE 40 oil cooler and used cooking oil, the surface hardness produced tends to be more stable. This is caused by the level of viscosity and boiling point of used SAE 40 oil and used cooking oil is higher compared to dromus. The use of cutting fluid results in the formation of a thin boundary film between the workpiece interface and the tool which can reduce the friction coefficient between the workpiece interface and the tool, resulting in a significant reduction in cutting forces. The high viscosity cutting fluid makes it possible to provide a high strength lubricating film which interacts strongly with the contact surface, this results in a low surface hardness [18, 19].
Effect of spindle speed on surface hardness

From the data in table 1 which is the result of the measurement of the surface hardness of the workpiece, then a graph is made of the relationship between the spindle speed and the surface hardness of the workpiece as shown in Figure 4. It can be seen from Figure 4 that the highest surface hardness occurs at a spindle speed of $665 \mathrm{rpm}$ and the lowest surface hardness occurs at a spindle speed of $1040 \mathrm{rpm}$.

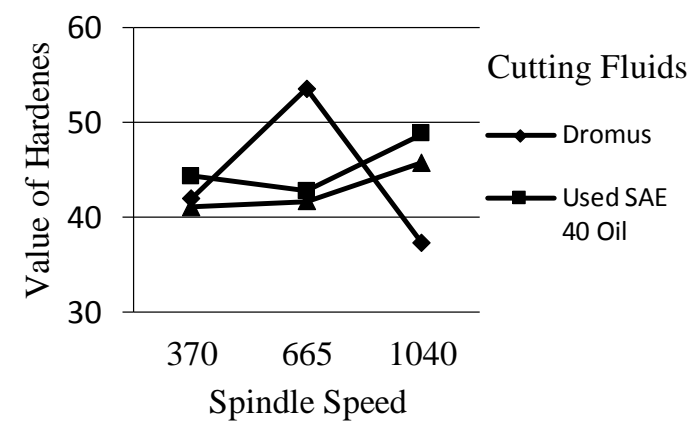

Figure 4. Graph of relationship between spindle speed and surface hardness

At the spindle speed of $665 \mathrm{rpm}$ the surface hardness that occurs is higher than the spindle speed 370 , this is because the higher the spindle speed, the temperature will also be higher. Whereas at the spindle speed of 1040 the surface hardness that occurs is getting lower, this is due to the high spindle speed which will produce a stable rotation so that the feeding load becomes small [20].

\section{Analysis of variance}

To determine the effect/contribution of each parameter on the surface hardness of the workpiece, analysis of variance (ANOVA) is used. From the data obtained in the hardness test then used to find the values in the ANOVA table as in Table 2.

Table 2. Analysis of Variance

\begin{tabular}{lclll}
\hline \multicolumn{1}{c}{ Factor } & SS & DF & MSS & FC \\
\hline $\begin{array}{l}\text { Cutting } \\
\text { fluid }\end{array}$ & 9286 & 2 & 4643 & 72268 \\
\hline $\begin{array}{l}\text { Spindle } \\
\text { speed }\end{array}$ & 5258090 & 2 & 262904 & 72769 \\
\hline Interaction & -289369 & 4 & 72342 & 72933 \\
\hline Error & -3400488 & 18 & 26306 & - \\
\hline Total & 4071955 & 2 & - & - \\
\hline
\end{tabular}


1. Test the effect of cutting fluid on the hardness of AISI 4140 steel

Ho = cutting fluid does not affect the surface hardness of AISI 4140 steel.

$\mathrm{H} 1$ = cutting fluid affects the surface hardness of AISI 4140 steel.

$\mathrm{Ho}$ is rejected if $\mathrm{Fc}$ is greater than $\mathrm{Ft}$ $(\mathrm{Fc}>\mathrm{Ft})$.

If using $\alpha=0.05$, the obtained value of $\mathrm{Ft}=3.29$. Because $\mathrm{Fc}=72268$, then $\mathrm{Fc}$ $>\mathrm{Ft}$, so Ho is rejected. This means that the coolant affects the surface hardness of the AISI 4140 steel turning process.

2. Test the effect of spindle speed on the hardness of AISI 4140 steel

Ho $=$ spindle speed does not affect the surface hardness of AISI 4140 steel.

$\mathrm{H} 1=$ spindle speed affects the surface hardness of AISI 4140 steel.

By using $\alpha=0.05$, the obtained value of $\mathrm{Ft}=3.29$. Because $\mathrm{Fc}=72769$, $\mathrm{Fc}>\mathrm{Ft}$ so that Ho is rejected. Which means that the spindle speed affects the surface hardness of the AISI 4140 steel turning process.

3. Test the interaction between cutting fluid and spindle speed on the hardness of AISI 4140 steel

Ho $=$ there is no interaction between the cutting fluid and spindle speed on the surface hardness of AISI 4140 steel.

$\mathrm{H} 1=$ there is an interaction between the cutting fluid and spindle speed on the surface hardness of AISI 4140 steel.

If using $\alpha=0.05$, the obtained value of $\mathrm{Ft}=3.42$. Because $\mathrm{Fc}=72933$, then $\mathrm{Fc}$ $>\mathrm{Ft}$ so that Ho is rejected. Means that there is an interaction between the cutting fluid and spindle speed in influencing the surface hardness of AISI 4140 steel in the turning process.

\section{Conclusions}

From the results of research about effect of cutting fluid and spindle speed on surface hardness in turning AISI 4140 steel, can be concluded as follows: The cutting fluid affects the surface hardness in the turning process of AISI 4140 steel. Dromus cutting fluid produces fluctuating surface hardness compared to used SAE 40 oil cutting fluid and used cooking oil cutting fluid which tends to be more stable. Spindle speed affects surface hardness in the turning process of AISI 4140 steel. High spindle speeds produce low surface hardness in dromus cutting fluid and conversely high spindle speeds produce high hardness in used SAE 40 oil cutting fluid and used cooking oil cutting fluid.

\section{Acknowledgement}

The authors gratefully acknowledge to Universitas Muhammadiyah Sidoarjo for technical supporting and financially.

\section{References}

[1] Trent, E.M. \& Wright, P.K., 2000. Metal-Cutting, 3rd edition, Butterworth Heinemann, Boston.

[2] T. S. Ogedengbe, P. Awe, and O. I. Joseph, 2019. Comparative analysis of machining stainless steel using soluble and vegetable oils as cutting fluids. International Journal of Engineering Materials and Manufacture 4(1), 33-40.

[3] Taufiq Rochim, 1993. Theory and machining process technology. Department of Mechanical Engineering, ITB, Bandung.

[4] Iswanto, et al., 2020. Effect of the cutting angle and the depth of cut toward wear of carbide tool on the lathe. Journal of Physics: Conference Series 1594, 012027.

[5] Black J. T. \& Kohser R. A., 2017. De Garmo's materials and processes in manufacturing. John Wiley \& Sons.

[6] Rozaq, M.M. and Iswanto, 2017. Analisa pengaruh gerak makan dan putaran spindel terhadap keausan pahat pada proses bubut konvensional. R.E.M. (Rekayasa Energi Manufaktur) Jurnal 2(1), 1318.

[7] Mia, M. and Dhar, N.R., 2015. Effect 
of high pressure coolant jet on cutting temperature, tool wear and surface finish in turning hardened (Hrc 48) steel. Journal of Mechanical Engineering 45(1), 1-6.

[8] Ogedengbe, T.S. et al., 2019. The effects of heat generation on cutting tool and machined workpiece. Journal of Physics: Conference Series 1378(2), 1-10.

[9] Chavoshi, S.Z. and Tajdari, M., 2010. Surface roughness modelling in hard turning operation of AISI 4140 using $\mathrm{CBN}$ cutting tool. International Journal of Material Forming 3(4), 233-239.

[10] Mia, M. and Dhar, N.R., 2017. Optimization of surface roughness and cutting temperature in highpressure coolant-assisted hard turning using Taguchi method. International Journal of Advanced Manufacturing Technology 88(1-4), 739-753.

[11] Thiele, J.D. and Melkote, S.N., 1999. Effect of cutting edge geometry and workpiece hardness on surface generation in the finish hard turning of AISI 52100 steel. Journal of Materials Processing Technology 94(2), 216-226.

[12] Gurun, H. et al., 2018. Investigation of the effects of cutting parameters on the surface roughness in the turning of AISI 1050 steel. Proceedings of 4th ICENS, Ukraine, 305-310.

[13] Dhar N. et al., 2010. Effect of minimum quantity lubrication (MQL) on tool wear, surface roughness and dimensional deviation in turning AISI-4340 steel. Gazi University Journal of Science 20(2), 23-32.

[14] Namb, M. and Paulo, D., 2011. Influence of coolant in machinability of titanium alloy (Ti-6Al-4V). Journal of Surface Engineered Materials and Advanced Technology 1(1), 9-14.

[15] Kumar, N.S. et al., 2012. Effect of spindle speed and feed rate on surface roughness of carbon steels in $\mathrm{CNC}$ turning. Procedia Engineering 38, 691-697.

[16] Onuoha O. J. et al., 2016. Determining the effect of cutting fluids on surface roughness in turning AISI 1330 alloy steel using Taguchi method. Modern Mechanical Engineering 6(2), 51-59.

[17] Setyawan, A.H. and Iswanto, 2019. Pengaruh putaran spindel dan cairan pendingin terhadap kekasaran permukaan baja AISI 4140 pada proses pembubutan. R.E.M. (Rekayasa Energi Manufaktur) Jurnal 4(1), 1-15.

[18] Xavior, M.A. and Adithan, M., 2009. Determining the influence of cutting fluids on tool wear and surface roughness during turning of AISI 304 austenitic stainless steel. Journal of Materials Processing Technology 209(2) 900-909.

[19] Lawal, S.A. et al., 2014. Evaluation of vegetable and mineral oil-in-water emulsion cutting fluids in turning AISI 4340 steel with coated carbide tools. Journal of Cleaner Production 66, 610-618.

[20] Yousefi, S. and Zohoor, M., 2019. Effect of cutting parameters on the dimensional accuracy and surface finish in the hard turning of MDN250 steel with cubic boron nitride tool, for developing a knowledged base expert system. International Journal of Mechanical and Materials Engineering 14(1), 1-13. 